\title{
What field education experiences do social services students regard as meaningful?
}

Niina Manninen, Elina Kuusisto \& Kirsi Tirri

\section{ABSTRACT}

- The purpose of this study was to investigate the kinds of field education experiences that social services students $(N=113)$ regard as meaningful. The theoretical structure was based on a "purpose of life" framework (Damon, Menon \& Bronk 2003). Pursuing a helping profession is identified as a life purpose when it is a personally meaningful long-term life goal that is intentionally realized by benefiting others. Based on quantitative and qualitative data, the study relates the students' meaningful field education experiences to a sense of community, learning professional competencies, and learning related to the self. Students' confidence in helping and in social advocacy increased after their field education, and they were less concerned with searching for purpose. Helping seems to be an important life goal for the students but explicitly reflecting its pro-social meanings does not seem apparent.

Keywords: social services students, field education, purpose of life, purpose in helping 


\title{
TIIVISTELMÄ
}

\section{MITÄ TYÖHARJOITTELUKOKEMUKSIA SOSIONOMIOPISKELIJAT PITÄVÄT MERKITYKSELLISINÄ?}

—ämän tutkimuksen tavoitteena oli selvittää, millaisia työharjoittelukokemuksia sosionomiopiskelijat ( $\mathrm{N}=113$ ) pitivät merkityksellisinä. Tutkimuksen teoreettisena viitekehyksenä on "elämän tarkoituksen" määritelmä (Damon, Menon \& Bronk 2003). Auttamisammatin tavoittelu määritellään elämän tarkoitukseksi, mikäli se on henkilökohtaisesti merkityksellinen pitkän tähtäimen tavoite, joka tietoisesti toteutetaan muiden hyödyksi. Laadullisen ja määrällisen aineiston perusteella opiskelijoiden merkittävät kokemukset koskivat yhteisöllisyyttä sekä ammattiin ja itseen liittyvään oppimista. Luottamus omiin auttamisen ja sosiaalisen asianajon taitoihin kasvoi harjoittelun aikana, ja opiskelijat kokivat vähemmän tarvetta etsiä elämän tarkoitusta. Auttaminen vaikuttaa olevan tärkeä elämäntavoite opiskelijoille, mutta sen prososiaalisten merkitysten eksplisiittinen reflektointi ei ole kuitenkaan ilmeistä.

Avainsanat: Sosionomiopiskelijat, työharjoittelu, elämän tarkoitus, auttaminen elämän tarkoituksena

\section{Introduction}

\begin{abstract}
A the Metropolia University of Applied Sciences in Helsinki, Finland, which is the context for this study, social services students are educated to become qualified professional helpers (see GuggenbuhlCraig 1971). Professional helpers use deliberate and specified attempts in addressing their clients' varying needs and helping them to cope within challenging life situations (Guggenbuhl-Craig 1971). We set out to determine whether these students consider helping and social advocacy to be their life purpose. Thus, this mixed methods study investigates the students' meaningful field education experiences in relation to a theoretical "purpose of life" framework. Purpose of life is defined as "a stable and generalized intention to accomplish something that is ance meaningful to the self and of consequence to the world beyond the self" (Damon, Menon \& Bronk 2003, 121). At best, the students' field education can promote their identification with helping as a life purpose through offering concrete opportunities to help the clients and advocate for their rights and for social improvements in general (see Malin et al. 2013).
\end{abstract}


Purpose of life framework is particularly important in studying social services students' pursuits due to its pro-social emphasis. This pro-social (other-benefiting) emphasis separates the concept from the meaning of life (Damon et al. 2003). Purposeful people have identified their life purpose, act on that purpose (Damon 2008), and are able to explicate how and why their life purpose would benefit the world beyond themselves (Moran 2009). Consequently, purpose refers to both personal and social level implications. Balanced self- and other-focused reasoning is indicative of those who have a purpose in life (Bronk \& Finch 2010). Having a helping purpose, for example, means that one considers helping to be a personally meaningful, long-term life goal whose importance is justified by including a focus both on the self and on others, that is, how and why one's activities are intended to benefit the clients or the society (see Bronk \& Finch 2010; Damon et al. 2003; Moran 2009). Thus, for example, helping based on selffocus only is not considered an authentic life purpose (see Moran 2009).

Why, then, is it important to study social services students' identification with helping as a life purpose? And why is it important to define their purposefulness? One answer is that having a purpose in life is associated with healthy and productive behaviors. Having no sense of purpose, on the other hand, is associated, for example, with depression, self-absorption, lack of productivity and unstable interpersonal relationships. (Damon et al. 2003.) Having a sense of purpose in social services work has been associated with better job satisfaction in comparison with having no sense of purpose (Itzick, Kagan \& Ben-Ezra 2018). Social services professionals should also be able to recognize how their position values in their clients' lives: how their own cultural practices, values and purposes influence clients (McBeath \& Webb 2002).

Emphasizing the social aspects in life, such as varied cultural practices, is elementary in the students' social pedagogical education at the Metropolia University of Applied Sciences (see Social Services Curriculum 2018). Advancing social responsibility while people pursue their individual goals is a central aim of social pedagogy (Hämäläinen 2015). Social pedagogy aims at promoting people's social functioning, participation, social identity, and social competence as members of society (Storø 2013). In social pedagogy, it is considered important to help people achieve their full potential through holistic relationship-based education (Úcar 2013), which could include identification and development of their deeper purposes. Promoting the development of purpose in others is a 
skill that should be essential in social services work (Chan 2017). People who have identified their own purposes are better able to promote the purpose development in others (Tirri \& Kuusisto 2016).

In a previous study of the authors, the social services students studied here rated, when measured on a Likert scale, helping others in third place as an important life-long goal. Their most important life goals were close relationships and hedonistic pursuits. Further qualitative inspection of how the students explained their long-term life goals shows that most of them (59 percent) justified their pursuits through self-focus only, 23 percent justified their life goals in the importance to themselves and to unknown others, or generally wanting to advance the betterment of the world, while 18 percent addressed the benefit of their life goals to themselves and to those closest to them. (Manninen, Kuusisto \& Tirri 2018.) In Likert scale (five point) answers, social services students' rate benefiting themselves and their closest people higher ( $\mathrm{M}$ $=4.30, \mathrm{SD}=.80)$ than benefiting unknown others or advancing societal development in general $(\mathrm{M}=3.55, \mathrm{SD}=1.04)$ (Manninen, Kuusisto \& Tirri, forthcoming).

Based on these findings, most of the students can be described as Dabblers. They already experience a relatively high sense of purpose, but they still seek new purposes. (Manninen, Kuusisto \& Tirri, forthcoming.) Moran (2009) has stated that Dabblers are often engaged in pro-social activities, such as pursuing a helping profession, but they do not seem to be aware of why and how their activities are meaningful, not only to themselves but also to others or for the greater good. Most of the students we studied could not articulate any values or principles that would guide their lives in general or steer their helping activities (Manninen, Kuusisto \& Tirri, forthcoming).

Structured opportunities in helping and in social advocacy, such as in field education, can further purpose development because of the opportunities offered to act for the benefit of others (Malin et al. 2013). Purpose development has also been associated with a sense of community (Tirri \& Quinn 2010), with skills and competencies in pursuing one's life goals (Damon 2008), and with developing self-awareness in regard to these pursuits (Moran 2009). The students' ability to explain their lifelong pursuits, such as helping, through both self- and other-focus seem to be central to developing purpose (see Bronk \& Finch 2010; Moran 2009). 
Consequently, this study endeavors to answer the following research questions:

1) What field education experiences do students regard as meaningful?

2) Do the students explicitly indicate other-focused reasoning in their meaningful field education experiences?

3) How does the students' confidence and satisfaction in helping and in social advocacy change in field education?

4) How does the social services students' sense of purpose change during field education?

\section{Data and Methods}

\section{Participants}

The study sample is comprised of social services students $(\mathrm{N}=113)$ who participated in field education during the fall semester of 2015 at the Metropolia University of Applied Sciences in Helsinki, Finland. Respondents answered online surveys (Moran 2014), which included the same instruments before and after their field placements. The response rate for the first questionnaire was 96 percent; the rate for the final questionnaire was 75 percent. The mean age of the respondents was 27 years $(S D=6.77, \min =20$ years, $\max =52)$. The majority of the participants were women, with only eight percent being men. 8.8 percent $(\mathrm{N}=10)$ were with immigrant background in Finland and 91.2 percent $(\mathrm{N}$ $=103$ ) with non-immigrant background. Participants were first-year $(\mathrm{n}=$ $31 ; 27$ percent), second-year $(n=52 ; 46$ percent), and final year $(n=30$; 27 percent) students. The length of the first-year field placement was four weeks, the second-year placement lasted eight weeks, and the final year field placement was twelve weeks. To earn a bachelor of social services degree takes three and a half years in Finland and includes 210 credits. (See Social Services Curriculum 2018.)

In their field education, most of the students worked with children, young people, and families in different educational and social settings ( $\mathrm{n}=70,62$ percent), such as kindergartens, schools, and children's homes. The remaining students helped adults or the elderly or worked in non-governmental organizations. Due to the small sample size and disproportion in the year groups, comparisons of pre- and post-field education are made at the level of the whole group, not with regard to differences between the first-, second-, or final-year groups. 


\section{Instruments}

Students answered pre- and post-field education questionnaires. In the post-field education survey (Moran 2014) the students answered the openended question: What was the most influential field education experience during the semester and why? Of 112 open answers, 103 were analyzed, including 157 meaning units in total (see Graneheim \& Lundman 2004). If the meaning of an answer was unclear, it was left uncoded ( 9 answers). In uncoded answers, a student might mention his or her learning, for example, but not describe the content in detail; or the students wrote only the name of a client group and nothing else.

Pre- and post-questionnaires included Moran's (2014) scales for confidence and satisfaction in helping and social advocacy. Using a fivepoint Likert scale ( $1=$ not at all, $5=$ greatly), students answered the question of how confident they felt in helping and in social advocacy and how satisfied they think they would feel in making an impact in helping and social advocacy during their lifetime. The confidence dimension was based on the following statement: I have confidence in my ability to: 1) directly help other people, 2) set up and start organizations that help, 3) advocate for social improvements. The satisfaction dimension was measured by the question: Over the course of my life, I would feel satisfied if I made an impact by 1) directly helping other people, 2) setting up organizations that help, 3) advocating for social improvements. Sum variables were created based on the three items that measured confidence in helping and in social advocacy and on the three items that measured satisfaction in making an impact by helping and through social advocacy as life-time pursuits. The alphas were calculated from the first data gathering for confidence in helping and social advocacy $(\alpha=.74)$ and the satisfaction with these goals $(\alpha=.68)$.

The sense of students' purpose was measured with Steger, Frazier, Oishi, and Kaler's (2006) meaning-of-life questionnaire, with using items to measure the search for purpose $(\alpha=.89)$ and the presence of purpose ( $\alpha$ $=.84$ ). Again the alphas were calculated from the first data gathering. On this instrument the students answered the following questions on a sevenpoint Likert scale ( $1=$ absolutely untrue, $7=$ absolutely true). The scale on search for purpose included the items: I am searching for meaning in my life; I am looking to find my life's purpose; I am looking for something that makes my life feel meaningful; I am searching for something that makes my life feel significant; I am seeking a purpose or mission for my life. The 
presence of purpose included the items: I understand my life's meaning; My life has a clear sense of purpose; I have a good sense of what makes my life meaningful; I have discovered a satisfying life purpose; My life has no clear purpose (the final item being reverse coded).

\section{Data analysis}

Qualitative content analysis. Many of the students' answers were in a short form and included one field education experience identified by the student as the most influential. These specific cases were understood as meaning units (see Graneheim \& Lundman 2004). If more than one meaning unit was mentioned in an answer, the units were coded in different categories and later quantified. The qualitative content analysis was conducted inductively (Elo \& Kyngäs 2008) by examining the students' most influential field education experiences. The names of the inductively created main categories were based on the content of the meaning units as follows: 1) experiences related to a sense of community, 2) learning related to professional competencies, and 3) learning related to oneself that is considered as improved self-awareness. Since the students' most often mentioned (47 percent) influential field education experiences were related to different aspects of a "sense of community," these cases were further analyzed deductively (Elo \& Kyngäs 2008) using McMillan and Chavis's (1986) definition, chosen for its comprehensive nature.

According to these authors (McMillan \& Chavis 1986), a sense of community includes the following categories: membership, influence, integration and fulfilment of needs (reinforcement), and emotional connections. In practice, these categories often overlap and are difficult to distinguish, the reason being that the psychological experience of a sense of community or the lack of it unfolds and manifests in complex ways (see McMillan \& Chavis 1986). Despite this overlap, these categories were found in the students' open answers, as follows:

1) answers about acceptance in the community and experiences of being part of a team were coded in the membership category;

2) students' answers that indicated the work was meaningful to clients and showed how the activities influenced clients' lives positively (generally by considering the client's perspective, that is, the "otherfocus") were coded in the influence category;

3) when the students described reinforcement by giving evidence that 
they had been trusted and given responsibilities, the sentences were classified in the integration and fulfilment of needs category.

With regard to emotional connections, none of the students described emotional connectivity as such, but rather as a general encounter with clients or with field supervisors.

Finally, the other-focus in the students' answers was analyzed by calculating whether a student explicitly addressed a perspective other than his or her own in describing the most influential experience or in how their activities influenced others; in other words, the student explicitly addressed the clients' perspective. Also, the subcategory of influence was interpreted as representing the students' other-focused reasoning in that they reflected on how their activities influenced the community or the clients. "Other-focus" was classified in the categories of emotional connections and learning professional competencies in addition to influence. Table 1 shows the categories, subcategories, quantification, and example quotations from the data.

Statistical analyses. In the statistical testing, the normality of the differences was first checked for before-and-after field education measures using the Kolmogorov-Smirnov test. Since differences were not normally distributed for these scales with a $p$-value of .000 nonparametric related-samples, a Wilcoxon signed-rank test was used to determine the differences between the before-and-after field education measures (see Petrie \& Watson 2013, 370). The calculation of effect sizes as $r$ for a Wilcoxon signed-rank test was based on calculating the following: $r=z$ score (value of observation in standard deviation units) divided by the square root of 226 (the number of all observations) (Field 2012, 234, 248). Cohen's criterion was used to interpret the effect sizes as: $r=.10$ (small effect); $r=.30$ (medium effect); $r=.50$ (big effect) (Cohen 1992). The results of statistical testing and the values of $z$ are presented in Table 2, showing an overall tendency of the measured differences before and after the field education: means and standard deviations, $z$ scores (related samples signed-rank test), significance level, and effect sizes as $r$ for statistically significant measures with $p$-value less than .05 . The statistically significant results are primarily discussed in the results section. 


$\begin{array}{llll}\begin{array}{l}\text { The most influential } \\ \text { field education } \\ \text { experience }\end{array} & \begin{array}{l}\text { Meaning } \\ \text { units }\end{array} & \begin{array}{l}\text { Other- } \\ \text { focused } \\ \text { reasoning }\end{array} & \begin{array}{l}\text { Examples of open answers } \\ \text { (quotations in italics illustrate } \\ \text { other-focus) }\end{array} \\ & \mathrm{F}=157 & \begin{array}{l}\mathrm{F}=157 \\ \mathrm{f}=29\end{array}\end{array}$

Experiences of a 77 (49\%)

sense of community:

Membership

10

I was openly accepted as part of the team, and I felt part of the team, even though I was not an employee (student 7).

Influence

I got people excited about the activities, and I got them to open up (student 100).

Fulfillment of

[The way I was accepted as part needs of the team]. I was trusted with a fair amount of responsibility, and I received lot of encouraging and positive feedback (student 14).

Emotional

27

9 I was able to establish a relationship connections with a client that enabled him to accept my help and helping was successful (student 67)

Learning
$\begin{aligned} & \text { professional } \\ & \text { competencies }\end{aligned}$

[l learned through encounters with children]. These taught me to consider the needs and wishes of quiet children (student 66).

Learning related to oneself Learning new aspects of myself (student 41).

Table 1. The most influential field education experiences and their other-focus

\section{Results}

\section{The influential field education experiences and their other-focus}

The students' key field education experiences were related to different aspects of experiencing a sense of community ( $f=77,49$ percent of the meaning units presented in Table 1 ). The emotional connections $(\mathrm{f}=27$ ) with clients or other people seemed to be the most influential dimension 
here, largely reflected by the students in the personal meaning only. In this category the students chiefly addressed all "encounters that were somehow meaningful" (student 11). A minority of the students ( $f=9$ ) explicitly considered the other-focus as the client's perspective in these encounters. The fulfilment of needs $(\mathrm{f}=23)$ through reinforcement was described as feeling valued: "The most influential [experience] was that I felt appreciated" (student 7). One's own influence on the community or on the clients was important to the students $(\mathrm{f}=17)$ : "I felt that I was able to help the client" (student 45) and "My work input was needed and helped the community" (student 7). Also membership ( $\mathrm{f}=10$ ) was mentioned as a feeling of being part of a team and the community: "I was accepted in the community and I was equal to others" (student 10). Explicit otherfocused reasoning was apparent in 29 meaning units, including emotional connections, influence, and learning related to professional competencies.

Learning professional competencies ( $f=52,33$ percent) refers to the concrete skills which students learned during their field education, for example, organizing group-based activities for clients and learning about work with a specific client group. "I organized a group-based activity in a primary school. I planned the activity well, and it was nice to see how the activity progressed the way I had planned it" (student 93). Students who showed explicit other-focused reasoning with regard to professional learning explained, for example, "The concerns of helping the parents made me think about the development of the children and how they progress, because those innocent children are the ones that I want to help. The regression of parents or static situations in a family prohibit children from making progress" (student 78). "The field education experience as a whole [was the most influential]. I liked how the development of the work practices was always apparent, and the innovative solutions really benefited the clients" (student 77).

Students also wrote of learning about themselves ( $\mathrm{f}=28,18$ percent), and these reflections could be considered as representing furthered selfawareness, such as "I learned a lot about myself" (student 11) and "I gained confidence in my own abilities as a bachelor of social services and as a kindergarten teacher and how I want to develop myself further" (student 1).

\section{Changes in students' perceptions}

Confidence and satisfaction in helping and in social advocacy. Students' confidence in helping as well as their satisfaction in making an impact by 


\begin{tabular}{|c|c|c|c|c|c|}
\hline Dimensions & $\begin{array}{l}M(S D) \\
\text { Before }\end{array}$ & $\begin{array}{l}M(S D) \\
\text { After }\end{array}$ & $Z$ & $P$ & $r$ \\
\hline $\begin{array}{l}\text { Confidence in helping } \\
\text { and advocating for } \\
\text { social improvements }\end{array}$ & $2.71(.66)$ & $3.33(.73)$ & 6.583 & .000 & .44 \\
\hline $\begin{array}{l}\text { Satisfaction over the course } \\
\text { of life to make an impact by } \\
\text { helping others and advocating } \\
\text { for social improvements }\end{array}$ & $3.96(.80)$ & $3.95(.73)$ & -.235 & .814 & \\
\hline Search for purpose & $5.19(1.25)$ & $4.70(1.39)$ & -3.974 & .000 & -.26 \\
\hline Presence of purpose & $4.98(1.13)$ & $5.17(1.11)$ & 1.931 & .053 & \\
\hline
\end{tabular}

Table 2. Development of confidence and satisfaction in helping and social advocacy and in a sense of purpose

Please note: Satisfaction and confidence in helping and in social advocacy was measured on a five-point Likert scale; search for and presence of purpose was measured on a sevenpoint Likert scale.

helping and through social advocacy as life-long pursuits were measured before and after the field education.

As can be seen in Table 2, the students' confidence in helping and in social advocacy grew significantly during their field education $(Z=6.583$, $p=.000, r=.44$ ), suggesting a relatively large effect. However, changes in satisfaction in making an impact through helping and social advocacy as life-time pursuits were not found, but this satisfaction was already on a relatively high level before the field education began $(M=3.96, S D=.80)$.

Sense of purpose. After field education, students' search for purpose decreased $(Z=-3.974, p=.000, r=-.26)$, suggesting a medium effect. However, the presence of purpose experienced by the students did not change significantly. Nevertheless, these results indicate that the felt sense of purpose grew, since afterwards the students were less concerned with searching for purpose. 


\section{Discussion}

The purpose of this study was to investigate the meaningful field education experiences of social services students $(N=113)$ in Finland. These experiences were defined in relation to the theoretical framework of the purpose of life (Damon et al. 2003), and specifically in terms of having a purpose in helping and social advocacy. Having a purpose in life is generally reflected in the subjective sense as well as through being engaged in pro-social activities as long-term pursuits (Damon et al. 2003) and justifying these through reasoning that includes both self- and otherfocus (Bronk \& Finch 2010), in other words, articulating how and why one's activities are meaningful personally and socially (see Moran 2009).

Purpose of life is closely associated with social pedagogy, which aims at promoting social responsibility (see Hämäläinen 2015). Analyzing and understanding social phenomena and their importance to human well-being is an essential aim of social pedagogical training at the Metropolia University of Applied Sciences (Social Services Curriculum 2018). Purpose of life could be an important element in achieving this goal: helping students to understand and explicitly address their deeper pursuits in the helping profession from both individual and also from wider societal perspectives. This could help the students to understand how they position values in social services work (see McBeath \& Webb 2002). Purposeful people are able to foster the development of purpose in others (Tirri \& Kuusisto 2016), and this should be essential in helping social services clients to make sense of their lives (Chan 2017; see also Úcar 2013). A sense of purpose in social services work helps to deal with the stress and improves job satisfaction (Itzick et al. 2018). And overall, having a purpose in life improves one's wellbeing (Damon et al. 2003).

As a result of the study, the students' meaningful field education experiences were related to a sense of community, to learning professional competencies, and to learning related to themselves, which previous studies have also identified as important aspects of purpose development (see Tirri \& Quinn 2010; Damon 2008; Moran 2009). The sense of community as the most often mentioned experience in the students' open answers ( $f=77,49$ percent) was further specified in McMillan and Chavis's (1986) framework, used here for its comprehensive nature. A sense of community was specified in order of frequencies as 1) emotional connections, in other words, encounters; 2) fulfilment of needs through 
reinforcement; 3) influence (on others); and 4) membership. Of these elements, emotional connections was the most often mentioned $(f=27)$, but often described just as an encounter and not reflected on a deeper level such as how one was able to build the emotional connections with clients and understand the clients' perspectives in the encounters. In total, other-focus as client perspective was explicitly addressed in 29 meaningful experiences out of 157 .

The students' confidence in helping and in social advocacy grew significantly in field education, showing a relatively large effect. On the other hand, their satisfaction with making an impact through helping and social advocacy remained on the same level as before the field education. It seems that the students consider helping and social advocacy as an important life-time goal. Yet, the concrete activities in benefiting clients during the field education did not increase the importance of this life goal. Nevertheless, after the field education, the students felt less need to search for their purposes. It seems that the students' increased sense of purpose in field education is not only related with the improved skills in helping and supporting others but also with fulfilling their personal needs such as feeling of belonging and developing one's self-awareness.

In a study of the authors (forthcoming), most of the Finnish social services students were identified as Dabblers. Dabblers are not usually aware of why they are engaged in other-benefiting activities, such as helping, nor are they aware of the implications of these activities (Moran 2009). People who identify the pursuit of a helping profession as their purpose are aware of why they are engaged in it and the social implications of it. Based on this current study, the pursuit of a helping profession seems to be a personally meaningful life goal for the students but most of them do not explicitly address the social, other-focused, aspects in helping. Having a genuine purpose in helping unknown others is perhaps, of relevance to a number of students, but not for all. Purpose can also be found in familial concerns, for example.

As a limitation of the study, it must be noted that the students' answers to the question of their meaningful field education experiences were short. It must also be noted that the length of the students' field education varied, and the sample represents students in different years and with different prior experiences in the field. Furthermore, the study is based on a relatively small sample. Despite these limitations, our study shows that in some ways the field education helped the students to experience a better 
sense of purpose. Still more research is needed on how the students' selfand other-focused reasoning about helping and social advocacy-related activities develops at different stages of their social pedagogical education.

Potentially field education can help social services students to identify helping as a life purpose because it offers structured and concrete opportunities to act for the benefit of clients (see Malin et al. 2013). According to this study the students seem to be satisfied with making an impact through helping and social advocacy as a life-long goal. The students' sense of purpose grew but explicitly reflecting on the beyondthe-self aspects in the meaningful field education experiences was not that apparent. Based on this study it seems important to develop the students' identification with the beyond-the-self, social aspects in purposeful, social pedagogically oriented helping (see Hämäläinen 2015; also Storø 2013; Social Services Curriculum 2018; Úcar 2013).

\section{REFERENCES}

Bronk, K. C. \& Finch, W. H. 2010. Adolescent characteristics by type of long-term aim in life. Applied Developmental Science 14 (1), 1-10. DOI: 10.1080/10888690903510331

Chan, W. C. H. 2017. Assessing meaning in life in social work practice: Validation of the Meaning in Life Questionnaire among clinical samples. British Journal of Social Work 47 (1), 9-27. DOI: 10.1093/bjsw/bcv144

Cohen, J. 1992. A power primer. Psychological Bulletin 112 (1), 155-159.

Damon, W. 2008. The Path to Purpose. How Young People Find Their Calling in Life. New York: Free Press.

Damon, W., Menon, J. \& Bronk, K. C. 2003. The development of purpose during adolescence. Applied Developmental Science 7 (3), 119-128.

Elo, S. \& Kyngäs, H. 2008. The qualitative content analysis process. Journal of Advanced Nursing 62 (1), 107-115. DOI: 10.1111/j.1365-2648.2007.04569.x

Field, A. 2012. Discovering statistics using IBM SPSS statistics. Fourth edition. London: Sage Publications.

Graneheim, U. H. \& Lundman, B. 2004. Qualitative content analysis in nursing research: concepts, procedures and measures to achieve trustworthiness. Nurse Education Today 24 (2), 105-112. DOI: 10.1016/j.nedt.2003.10.001

Guggenbuhl-Craig, A. 1971. Power in the Helping Professions. Dallas: Spring Publications, Inc.

Hämäläinen, J. 2015. Defining social pedagogy: Historical, theoretical and practical considerations. The British Journal of Social Work 45 (3), 1022-1038. DOI: 10.1093/bjsw/ bct174 
Itzick, M., Kagan, M. \& Ben-Ezra, M. 2018. Social worker characteristics associated with perceived meaning in life. Journal of Social Work 18 (3), 326-347. DOI: $10.1177 / 1468017316654345$

Malin, H., Reilly, T. S., Quinn, B. \& Moran, S. 2013. Adolescent purpose development: Exploring empathy, discovering roles, shifting priorities, and creating pathways. Journal of Research on Adolescence 24 (1), 186-199. DOI: 10.1111/jora.12051

Manninen, N., Kuusisto, E. \& Tirri, K. 2018. Life goals of Finnish social services students. Journal of Moral Education 47 (2), 175-185. DOI: 10.1080/03057240.2017.141587

Manninen, N., Kuusisto, E. \& Tirri, K. forthcoming. Finnish social services students' perceptions of purpose and helping unknown others.

McBeath, G. \& Webb, S. A. 2002. Virtue ethics and social work: being lucky, realistic, and not doing one's duty. The British Journal of Social Work 32 (8), 1015-1036.

McMillan, D. W. \& Chavis, D. M. 1986. Sense of Community: A definition and theory. Journal of Community Psychology 14 (1), 6-23.

Moran, S. 2009. Purpose: Giftedness in intrapersonal intelligence. High Ability Studies 20 (2), 143-159. DOI: 10.1080/13598130903358501

Moran, S. 2014. How service-learning influences youth purpose around the world, student semester start survey and end survey, Qualtrics version. USA/ Worcester: Clark University.

Petrie, A. \& Watson, P. 2013. Statistics for Veterinary and Animal Science. 3rd edition. Oxford: Wiley-Blackwell.

Social Services Curriculum 2018. Helsinki Metropolia University of Applied Sciences. Available online http://opinto-opas-ops.metropolia.fi/index.php/en/88094/en/70321/ SXG18S1/2000/year/2018 (Retrieved 12.3.2018).

Steger, M. F., Frazier, P., Oishi, S. \& Kaler, M. 2006. The meaning in life questionnaire: Assessing the presence and search for meaning in life. Journal of Counseling Psychology 53 (1), 80-93. DOI: 10.1037/0022-0167.53.1.80

Storø, J. 2013. Practical Social Pedagogy. Theories, values and tools for working with children and young people. Bristol: The Policy Press.

Tirri, K. \& Kuusisto, E. 2016. Finnish student teachers' perceptions of the role of purpose in teaching. Journal of Education for Teaching 42 (5), 532-540. DOI: $10.1080 / 02607476.2016 .1226552$

Tirri, K. \& Quinn, B. 2010. Exploring the role of religion and spirituality in the development of purpose: case studies of purposeful youth. British Journal of Religious Education 32 (3), 201-214. DOI: 10.1080/01416200.2010.498607

Úcar, X. 2013. Exploring different perspectives of Social Pedagogy: towards a complex and integrated approach. Education Policy Analysis Archives/Archivos Analíticos de Políticas Educativas 21 (36), 1-15. 
58 - Sosiaalipedagoginen aikakauskirja, vuosikirja 2018, vol. 19 